February 1980

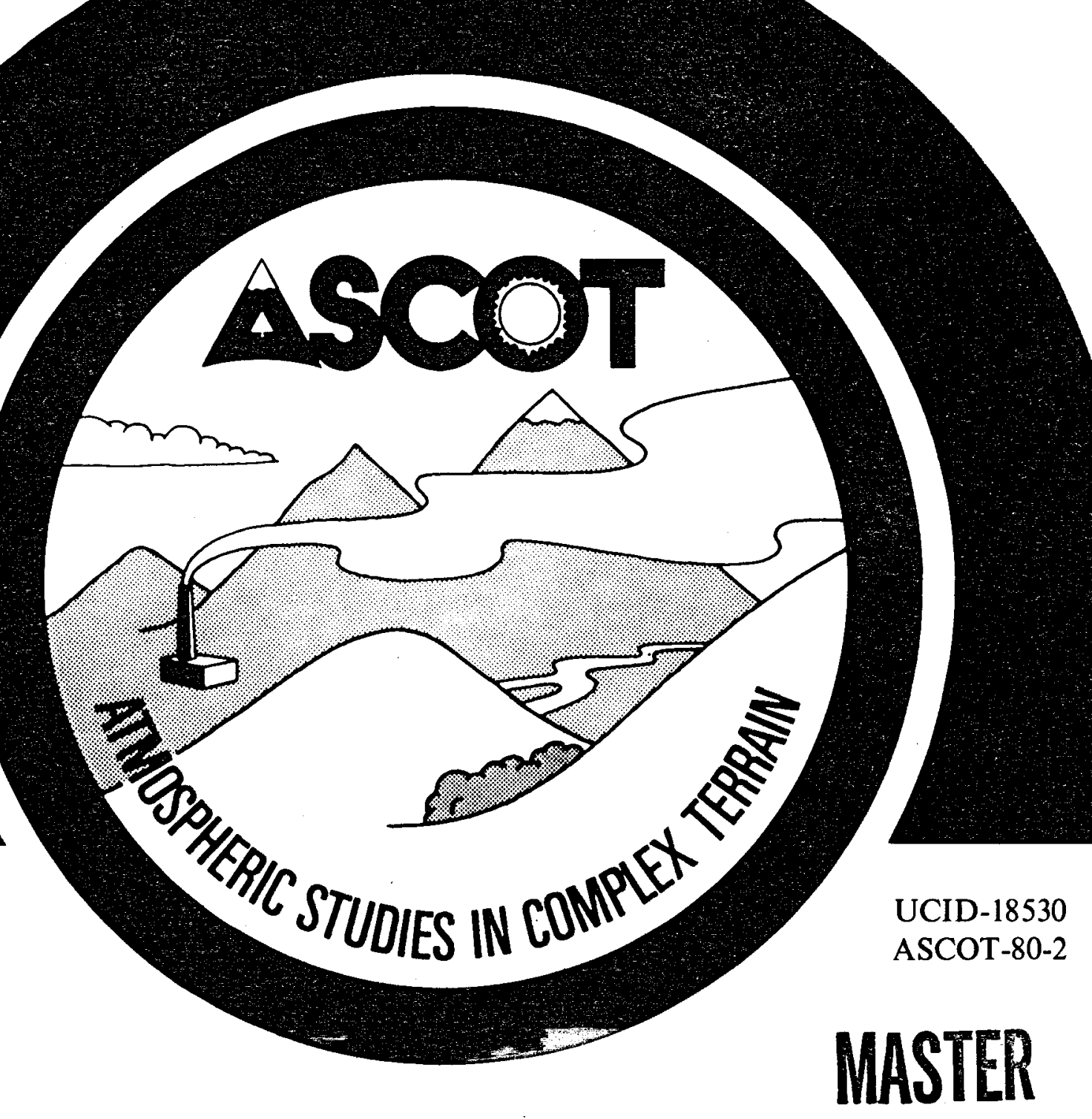

STATISTICAL ANALYSIS OF SUMMER WINDS IN GEYSERS AREA PRIOR TO ASCOT 1979 EXPERIMENT

\author{
William M. Porch \\ John J. Walton
}

Lawrence Livermore Laboratory, University of California Livermore, California 94550 


\section{DISCLAIMER}

This report was prepared as an account of work sponsored by an agency of the United States Government. Neither the United States Government nor any agency Thereof, nor any of their employees, makes any warranty, express or implied, or assumes any legal liability or responsibility for the accuracy, completeness, or usefulness of any information, apparatus, product, or process disclosed, or represents that its use would not infringe privately owned rights. Reference herein to any specific commercial product, process, or service by trade name, trademark, manufacturer, or otherwise does not necessarily constitute or imply its endorsement, recommendation, or favoring by the United States Government or any agency thereof. The views and opinions of authors expressed herein do not necessarily state or reflect those of the United States Government or any agency thereof. 


\section{DISCLAIMER}

Portions of this document may be illegible in electronic image products. Images are produced from the best available original document. 
$\mathrm{UCID}-18530$

ASCOT-80-2

\title{
STATISTICAL ANALYSIS OF SUMMER WINDS IN GEYSERS AREA PRIOR TO ASCOT 1979 EXPERIMENT
}

\author{
William M. Porch and John J. Walton \\ Lawrence Livermore Laboratory, University of California \\ Livermore, California 94550
}

February 1980

\section{ABSTRACT}

Statistical analytical techniques were tested on 73 days and 16 stations of hourly data for the summer of 1977. These stations were located in the region surrounding the Geysers geothermal area. Principal components analysis (PCA) was used to define typical wind patterns in the region and to determine typical days for each station. Power spectral analysis was used to quantify the temporal variation of winds at Anderson Ridge and Anderson Springs (two stations included in the ASCOT 1979 study in the local region of Anderson Creek with very different terrain exposures). These results will help determine year to year difference in the wind fields in the ASCOT study region of complex terrain.

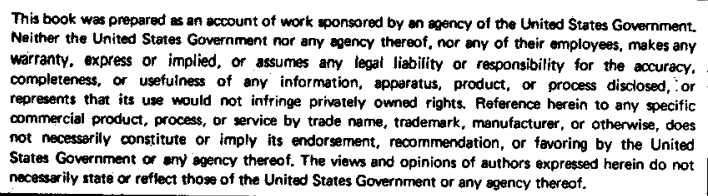




\section{INTRODUCTION}

The Atmospheric Studies in Complex Terrain (ASCOT) intensive experiment was conducted in July 1979 in the vicinity of Anderson Creek. In order to better understand the results of this experiment in the context of year to year variations, statistical analytical techniques were applied to previous wind data from 16 stations in the region during the summer of 1977. Comparisons will be made at a later date to see if there are substantial differences between the wind characteristics for the two years. The data base analyzed in this study contains data from over 50 stations in the region for 1976 and 1977. Because there were more stations in the immediate vicinity of Anderson Creek for the 1977 data than the 1976 period, the summer data for 1977 was used in this study. It was also decided that only 16 of the stations which had the least missing data periods and were closest to the Anderson Creek area would be used in this analysis.

Originally, it was thought that these stations had no missing data during the period selected (June, July and part of August). However, inspection of the data revealed periods of over six hours to over a day in which the wind speeds and directions listed in the data base showed no change at all. Since the primary statistical tools to be used to analyze the data (Principal Components Analysis (PCA) and Power Spectral techniques) require a continuous data set, these periods were treated as missing data and filled in using multiple linear regression equations based on relationships between the other stations. These relationship equations were based on periods when no data was missing and catagorized as night (2000 to 0600 PST) morning (0600 to 1000 PST) and day (1000 to 2000 PST). After this was done and the missing data were replaced, it was impossible to tell from casual inspection which periods originally had missing data. Nine hours each were replaced 
at Anderson Ridge and Anderson Springs and three periods of 14, 13, and 25 hours were filled for the Healdsburg data station out of a total of 1752 hours of data for the sixteen stations.

With the missing data periods replaced, the entire data set were then analyzed statistically to determine the temporal and spacial variability of the winds in this region. This serves not only to provide a characterization of the winds in the summer of 1977 but also as a test of the suitability of the statistical techniques chosen for providing insight into the wind field variability in this region of complex terrain.

The statistical method of PCA (frequently referred to as empirical eigenvector analysis) has been used at Lawrence Livermore Laboratory (LLL) to characterize the regional variation of wind fields for wind energy and pollution transport applications. 1 To do this PCA has been generalized to the treatment of vector measurements. Specifically, the observed wind velocities in mesoscale regions are treated by a generalized form. The primary mesoscale spatial velocity patterns are derived, and the method of time-series analysis in terms of the primary spatial patterns given by the principal components. Also, a method is used which permits the classification of days into groups with common characteristics. The application of PCA to the Geysers area data has shown that June and July 1977 data have very similar principal eigenvector patterns and that constructed typical days are intriguingly different for a ridge site (Anderson Ridge) than for a down valley site (Anderson Creek). There is approximately a four hour delay between the typical onset and breakup of drainage winds at the two locations.

More detail in the temporal variation of winds at these locations is derived from Power Spectral analysis. Digital power spectra are derived by making a fast Fourier transform of the covariance function derived from the data. This was-done 
for the individual wind components and the cosine of wind direction from due west winds for Anderson Ridge and Anderson Springs. From the results of these studies it was possible to separate on a frequency basis the stronger effect of large scale winds at Anderson Ridge and the stronger effect of nightime drainage winds at Anderson Springs. A detailed description of these results and other results from PCA and less sophisticated statistical procedures will be given in the next section.

\section{RESULTS}

As previously mentioned, the following results serve two purposes. First, these results can be compared to subsequent years data and differences determined. Secondly, they represent a test of the ability of the statistical procedures to provide insight into physical processes associated with complex terrain. The following statistical techniques have been used on the 1977 data set:

1. Multiple linear regression with associated correlation matrices, averages and standard deviations.

2. PCA and use of principal eigenvectors for typical data generation for each station.

3. Time-lagged correlation function analysis for the stations located at Anderson Ridge and Anderson Springs.

4. Power spectral analysis for these two stations.

The first two techniques relate the spatial variability of the day and the latter two with the temporal variability (temporal variability of the PCA generated typical day would represent a transition between spatial and temporal changes). The next paragraphs detail the results of these analyses. 
The 16 stations used in the analysis are shown in Table 1 along with their UTM coordinates and distance from Anderson Springs. Figure 1 shows Anderson Creek (Station 1) and some of the other more isolated stations on the map. Anderson Creek is in the area where most of the stations ( 1 through 9) are clustered. In the process of ruming multiple linear regression analysis to fill in missing data, the standard statistical matrix of means, standard deviations and correlations are generated. These are shown in Table 2 for the $U$ (west to east) and $V$ (south to north) wind speed components for 400 hours of data selected with no missing data during the same two weeks in July, 1977 that intensive measurements were made in 1979. From these data it is obvious that Anderson Ridge and Anderson Springs show very different wind characteristics in spite of their proximity. Obviously, this is because Anderson Ridge, as a ridge site, is higher and more exposed to large scale wind patterns including the possible influence of summer sea breezes in this region. Sea breezes generated by heating of the Sacramento Valley strongly influence the winds in the San Francisco Bay, area in the summer. This influence isn't as pronounced in the Geysers area but still exists and would be felt more strongly at ridge tops than in valleys. ${ }^{2}$ Anderson Springs is more influenced by drainage winds along Anderson Creek and more sheltered by topography. Anderson Ridge is seen to have the highest winds and Anderson Springs the lowest of the 16 stations. Anderson Springs $\mathrm{V}$ component winds tend to be negatively correlated with most the other stations and both $U$ and $V$ components are less correlated with the other stations than Anderson Ridge.

Table 3 summarized the results of the multiple regression analysis by showing just the number and stations selected using an F-Test criteria of 0.05 with Anderson Springs (A.S.) and Anderson Ridge (A.R.) as dependent variables with the percent variance explained without including the regression equations themselves. ${ }^{3}$ The 
TABLE 1. Stations Used in Analysis of 1977 Data in the Region of Anderson Creek.

\begin{tabular}{|c|c|c|c|c|}
\hline \multirow[b]{2}{*}{ No. } & \multirow{2}{*}{ Station } & \multicolumn{2}{|c|}{ UTM Coordinates } & \multirow{2}{*}{$\begin{array}{l}\text { Distance From } \\
\text { Anderson Ridge }\end{array}$} \\
\hline & & $\mathbf{X}$ & $\mathrm{Y}$ & \\
\hline 1 & Anderson Springs & 527.3 & 4292.1 & $0 \mathrm{~km}$ \\
\hline 2 & Whispering Pines & 525.2 & 4296.2 & 4.6 \\
\hline 3 & Sawmill Flats & 522.4 & 4298.6 & 5.1 \\
\hline 4 & Unit 16 & 525.3 & 4290.7 & 5.8 \\
\hline 5 & Middleton & 533.0 & $4289.0^{*}$ & 6.5 \\
\hline 6 & Geyser Rock & 520.1 & 4296.2 & 8.3 \\
\hline 7 & Pine Summit & 522.9 & 4300.3 & 9.3 \\
\hline 8 & Unit 1 & 517.4 & 4297.5 & 11.3 \\
\hline 9 & Wild Horse Canyon & 514.3 & 4299.8 & 15.1 \\
\hline 10 & Pope Valley & 544.9 & 4278.3 & 22.4 \\
\hline 11 & South Borax Lake & 527.4 & 4315.5 & 23.4 \\
\hline 12 & Healdsburg & 511.6 & 4273.5 & 24.3 \\
\hline 13 & Walker Ridge & 546.5 & 4322.8 & 36.2 \\
\hline 14 & Upper Lake & 508.8 & 4335.4 & 47.0 \\
\hline 15 & Lake Mendocino & 483.8 & 4339.1 & 64.0 \\
\hline 16 & Anderson Ridge & 522.8 & 4291.9 & 4.5 \\
\hline
\end{tabular}

independent variables (A.R. and A.S.) $U$ and $V$ components are separated as to whether they represent all hours of the day (total), 2000 to 0600 PST (night), 0600 to 1000 PST (morning) or 1000 to 2000 PST (day). It is obvious that the representative stations of the original 16 do a much better job explaining the variance at Anderson Ridge than Anderson Springs and that the variance in the $U$ component at both stations is easier to explain than the V. At Anderson Springs the night and morning winds which are predominantly influenced by drainage and morning upslope winds are significantly more difficult for the other stations to predict. This verifies that 


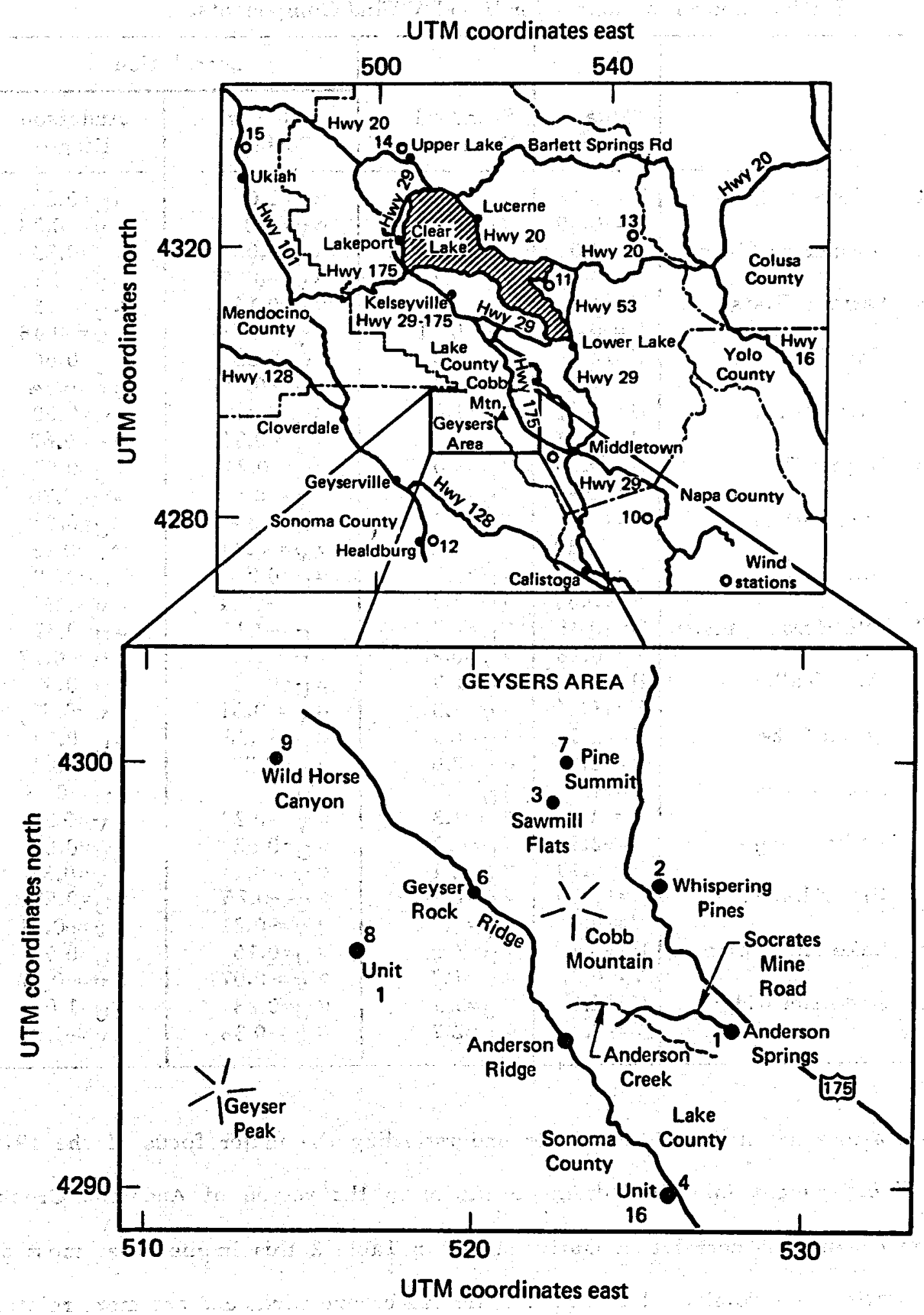

FIGURE 1. Placement of 16 wind data stations on a UTM coordinate grid. 
TABLE 2. Standard Statistics Determined from Multiple Linear Regression for 16 Stations Shown in Table 1 for $U$ and V Wind Components.

\begin{tabular}{|c|c|c|c|c|c|}
\hline \multirow[b]{2}{*}{ No. } & \multirow[b]{2}{*}{ Name } & \multirow[b]{2}{*}{$\begin{array}{l}\text { Mean } \\
(\mathrm{m} / \mathrm{s})\end{array}$} & \multirow[b]{2}{*}{$\begin{array}{l}\text { Standard } \\
\text { Deviation }\end{array}$} & \multicolumn{2}{|c|}{ Correlation } \\
\hline & & & & $\begin{array}{c}\text { Anderson } \\
\text { Spring }\end{array}$ & $\begin{array}{c}\text { Anderson } \\
\text { Ridge }\end{array}$ \\
\hline $\begin{array}{r}2 \\
3 \\
4 \\
5 \\
6 \\
7 \\
8 \\
9 \\
10 \\
11 \\
12 \\
13 \\
14 \\
15 \\
16\end{array}$ & $\begin{array}{l}\text { Anderson Springs } \\
\text { Whispering Pines } \\
\text { Sawmill Flats } \\
\text { Unit } 16 \\
\text { Middletown } \\
\text { Geyser Rock } \\
\text { Pine Summit } \\
\text { Unit } 11 \\
\text { Wild Horse Canyon } \\
\text { Pope Valley } \\
\text { Borax Lake } \\
\text { Healdsburg } \\
\text { Walker Ridge } \\
\text { Upper Lake } \\
\text { Lake Mendocino } \\
\text { Anderson Ridge }\end{array}$ & $\begin{array}{l}U=+0.12 \\
V=-0.30 \\
U=+0.02 \\
V=-0.88 \\
U=+1.3 \\
V=-0.47 \\
U=+2.5 \\
V=+0.2 \\
U=+0.61 \\
V=+0.78 \\
U=+0.65 \\
V=+0.34 \\
U=+2.1 \\
V=+0.49 \\
U=+0.42 \\
V=+0.44 \\
U=+0.45 \\
V=-0.18 \\
U=+1.3 \\
V=+0.96 \\
U=+1.3 \\
V=+1.4 \\
U=+1.0 \\
V=+1.2 \\
U=+2.3 \\
V=-0.79 \\
U=+0.90 \\
V=-0.01 \\
U=+1.43 \\
V=-0.22 \\
U=+2.7 \\
V=-2.2\end{array}$ & $\begin{array}{l}{ }^{\sigma} U=0.60 \\
\sigma_{V}=0.55 \\
\sigma_{U}=0.98 \\
\sigma_{V}=1.1 \\
\sigma_{U}=2.1 \\
\sigma_{V}=0.91 \\
\sigma_{U}=3.8 \\
\sigma_{V}=2.4 \\
\sigma_{U}=1.0 \\
\sigma_{V}=1.2 \\
\sigma_{U}=2.0 \\
\sigma_{V}=3.9 \\
\sigma_{U}=1.8 \\
\sigma_{V}=1.4 \\
\sigma_{U}=3.1 \\
\sigma_{V}=1.1 \\
\sigma_{U}=1.7 \\
\sigma_{V}=0.86 \\
\sigma_{U}=1.9 \\
\sigma_{V}=1.3 \\
\sigma_{U}=1.5 \\
\sigma_{V}=2.0 \\
\sigma_{U}=1.3 \\
\sigma_{V}=1.3 \\
\sigma_{U}=4.8 \\
\sigma_{V}=2.1 \\
\sigma_{U}=1.8 \\
\sigma_{V}=1.2 \\
\sigma_{U}=2.4 \\
\sigma_{V}=1.2 \\
\sigma_{U}=3.5 \\
\sigma_{V}=2.7\end{array}$ & $\begin{array}{l}{ }^{\alpha} U=1.0 \\
{ }^{\alpha} V=1.0 \\
{ }^{\alpha} U=0.08 \\
{ }^{\alpha} V=-0.09 \\
{ }^{\alpha} U=0.15 \\
{ }^{\alpha} V=+0.29 \\
\alpha_{U}=0.55 \\
{ }^{\alpha} V=-0.36 \\
{ }^{\alpha} U=0.21 \\
{ }^{\alpha} V=-0.36 \\
{ }^{\alpha} U=-0.21 \\
{ }^{\alpha} V=-0.5 \\
{ }^{\alpha} U=0.39 \\
{ }^{\alpha} V=-0.34 \\
{ }^{\alpha} U=0.09 \\
{ }^{\alpha} V=-0.44 \\
{ }^{\alpha} U=-0.35 \\
{ }^{\alpha} V=0.11 \\
\alpha_{U}=0.14 \\
{ }^{\alpha} V=-0.51 \\
\alpha_{U}=-0.38 \\
{ }^{\alpha} V=0.23 \\
\alpha_{U}=0.17 \\
\alpha_{V}=-0.23 \\
\alpha_{U}=0.52 \\
\alpha_{V}=-0.44 \\
\alpha_{U}=-0.25 \\
\alpha_{V}=-0.21 \\
\alpha_{U}=0.15 \\
\alpha_{V}=-0.07 \\
\alpha_{U}{ }_{U}=0.28 \\
\alpha_{V}=-0.38\end{array}$ & $\begin{array}{l}\alpha_{U}=0.28 \\
\alpha_{V}=-0.38 \\
\alpha_{U}=0.23 \\
\alpha_{V}=-0.17 \\
\alpha_{U}=0.75 \\
\alpha_{V}=-0.45 \\
\alpha_{U}=0.66 \\
\alpha_{V}=0.54 \\
\alpha_{U}=0.60 \\
\alpha_{V}=0.67 \\
\alpha_{U}=0.58 \\
{ }^{\alpha} V=0.70 \\
{ }^{\alpha} U=0.86 \\
{ }^{\alpha} V=0.73 \\
\alpha_{U}=0.59 \\
\alpha_{V}=0.51 \\
\alpha_{U}=0.32 \\
\alpha_{V}=-0.17 \\
\alpha_{U}=0.57 \\
\alpha_{V}=0.53 \\
\alpha_{U}=0.54 \\
\alpha_{V}=-0.46 \\
\alpha_{U}=-0.29 \\
\alpha_{V}=0.34 \\
\alpha_{U}=0.64 \\
\alpha_{V}=0.54 \\
\alpha_{U}=0.52 \\
\alpha_{V}=-0.01 \\
\alpha_{U}=0.53 \\
\alpha_{V}=-0.17 \\
\alpha_{U}=1.0 \\
\alpha_{V}=-1.0\end{array}$ \\
\hline
\end{tabular}

these stations are not well suited for understanding the major focus of the 1979 ASCOT experiment (nightime drainage winds) in the region of Anderson Creek. Combined with the correlation matrix shown in Table 2 this implies that most of these stations are dominated by larger scale sea breeze winds and are more related 
TABLE 3. Stations Selected and the Order of Standard Partial Regression with Percent Variance Explained using Multiple Linear Regression with an F-test of 0.05 .

\begin{tabular}{|c|c|c|c|}
\hline Variable & $\begin{array}{l}\text { F Test } 0.05 \\
\text { (stations included) }\end{array}$ & $\begin{array}{l}\text { Order of Standard } \\
\text { Partial Regression }\end{array}$ & $\begin{array}{l}\% \text { V ariance } \\
\text { Explained }\end{array}$ \\
\hline V-Total A.S. & $\begin{array}{l}3,6,8,10,11 \\
13,16\end{array}$ & $\begin{array}{l}10,8,16 \\
3,13,11,6\end{array}$ & $41 \%$ \\
\hline U-Total A.S. & $\begin{array}{l}4,5,6,9,11, \\
12,13\end{array}$ & $\begin{array}{l}5,11,6,12 \\
9,4,13\end{array}$ & $54 \%$ \\
\hline V-Total A.R. & $\begin{array}{l}1,2,3,6,7,8 \\
10,11,13,15\end{array}$ & $\begin{array}{l}1.7,3,6 \\
2,10,11,15 \\
8,13\end{array}$ & $75 \%$ \\
\hline U-Total A.R. & $\begin{array}{l}1,4,6,7,8,10 \\
13\end{array}$ & $\begin{array}{l}1,7,6,10 \\
4,8,13\end{array}$ & $86 \%$ \\
\hline V-Night A.S. & $3,11,13,16$ & $2,11,16,13$ & $11 \%$ \\
\hline V-Day A.S. & $\begin{array}{l}2,6,10,11,12 \\
13,16\end{array}$ & $\begin{array}{l}10,13,6,12 \\
2,16,11\end{array}$ & $32 \%$ \\
\hline V-Morning A.S. & $3,10,14$ & $14,10,3$ & $19 \%$ \\
\hline U-Night A.S. & $\begin{array}{l}2,5,6,8,10,13 \\
14,16\end{array}$ & $\begin{array}{l}2,6,5,14 \\
10,8,16,13\end{array}$ & $44 \%$ \\
\hline U-Day A.S. & $\begin{array}{l}3,4,7,9,11,12 \\
13,16\end{array}$ & $\begin{array}{l}7,11,12,4,9 \\
16,3,13\end{array}$ & $51 \%$ \\
\hline U-Morning A.S. & $4,6,10,14$ & $4,14,10,6$ & $39 \%$ \\
\hline V-Night A.R. & $\begin{array}{l}1,2,6,7,8,11 \\
12,15\end{array}$ & $\begin{array}{l}2,1,7,15,11 \\
8,12,6\end{array}$ & $58 \%$ \\
\hline V-Day A.R. & $\begin{array}{l}1,3,5,6,7,8 \\
10,11,14,15\end{array}$ & $\begin{array}{l}1,3,7,5,6, \\
11,10,8,15,14\end{array}$ & $65 \%$ \\
\hline V-Morning A.R. & $2,3,6,7,8,9,11$ & $\begin{array}{l}7,6,8,9,2 \\
11,3\end{array}$ & $79 \%$ \\
\hline U-Night A.R. & $1,4,6,7,8,9,13$ & $\begin{array}{l}1,8,6,7,9 \\
14,13\end{array}$ & $83 \%$ \\
\hline U-Day A.R. & $\begin{array}{l}1,3,4,5,6,7 \\
11,13\end{array}$ & $\begin{array}{l}1,5,6,7,4,3 \\
11,13\end{array}$ & $75 \%$ \\
\hline U-Morning A.R. & $3,6,7,8,13$ & $7,3,6,8,13$ & $90 \%$ \\
\hline
\end{tabular}


to Anderson Ridge than the more drainage wind dependent station Anderson Springs. PCA sheds more light on the spatial variability of these data.

The theory of wind pattern application of PCA has been described by Walton and Hardy. ${ }^{1}$ Here we will merely discuss its application to the regional winds in the Geysers geothermal area. In order to determine if large scale differences occur within the data, PCA was run separately for the months of June and July 1977. Geometric representations of the primary eigenvectors for these months are shown in Figs. 2 and 3. Two-dimensional vectors are defined at locations corresponding to the 16 measurement stations to indicate the direction of the local air flow. The magnitudes of the vectors indicate the relative wind speeds at each location. The figure of merit for the primary eigenvectors were 0.46 and 0.5 for June and July respectively. This parameter can vary from zero to unity and gives a measure of the mean-square significance of the primary eigenvector in a time-series expansion of the data. These values are somewhat lower than were found in a similar analysis of June and July data in the San Francisco Bay Area which presumably demonstrates a greater influence of complex topography for the Geysers area. The eigenvectors themselves show the dominance in the area of westerly winds and strong similarity of June and July wind patterns in the region. Healdsburg, the most southern station, had the most missing data and stands out in this analysis as either a most unusual station possibly influenced by channeling of wind from Bodega Bay or as having data of dubious value.

The temporal variability of the data is illustrated in Figs. 4 through 8 . Figure 4 shows the expansion coefficients associated with the primary spatial eigenvector for a selected period in June (June 24, 576 hours through June 30, 720 hours). The magnitude and the argument $\left(180^{\circ}\right.$ to $\left.-180^{\circ}\right)$ are separately plotted as a cross and a circle, respectively for each hour. The position of midnight during each day is 


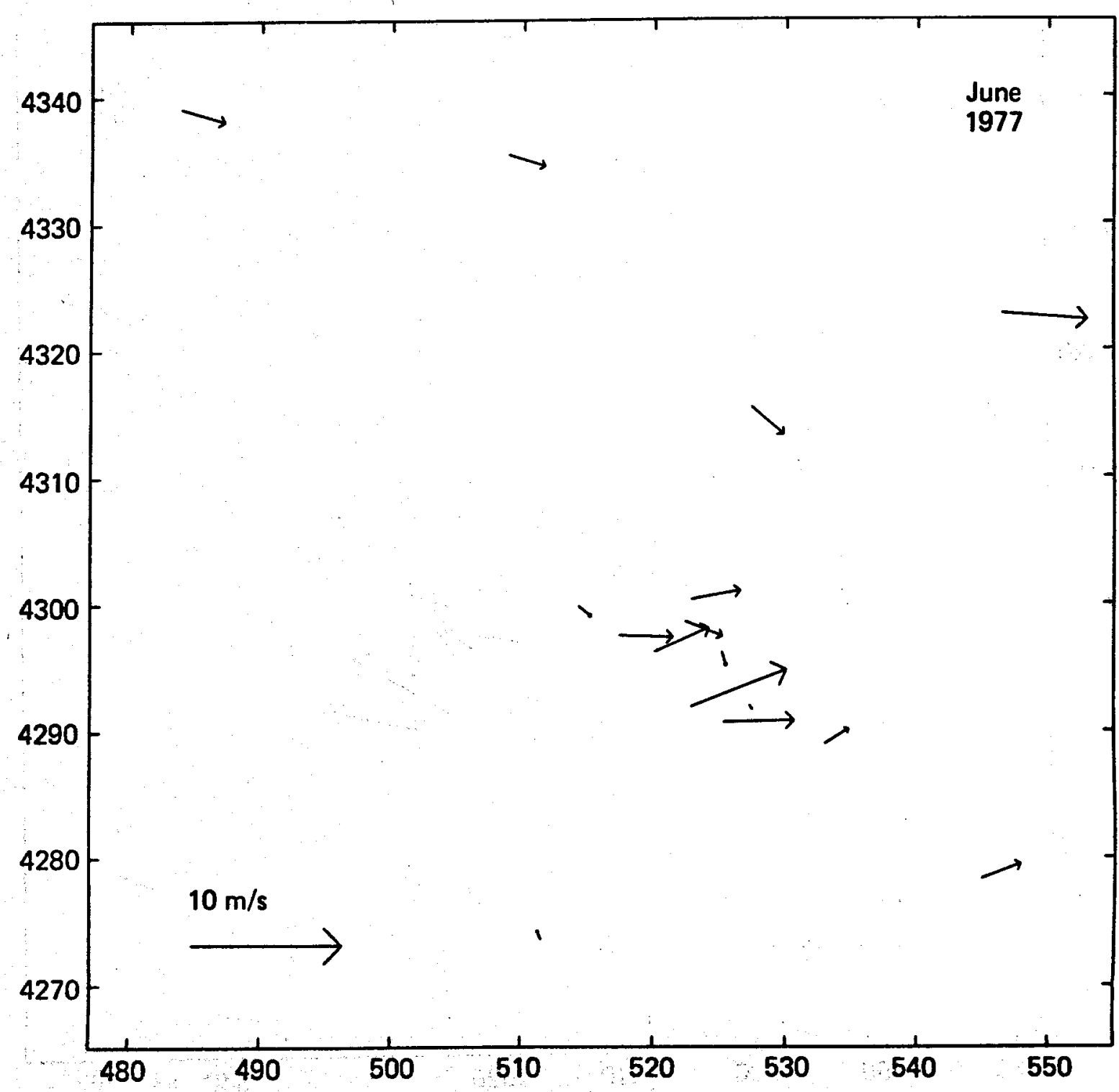

Fraction 4.62E-01

FIGURE 2. Principal eigenvector derived wind pattern and preferred direction for the month of Jume 1977 on grid shown in Fig. 1.

indicated at the top of each plot with a triangle. A common diurnal pattern of magnitude and direction is evident in these plots. The magnitude increase is due to increasing afternoon winds associated with sea breeze and local convective winds. The wind direction variation may be associated with sea breeze return flow or upslope drainage wind reversal caused by morning heating. 


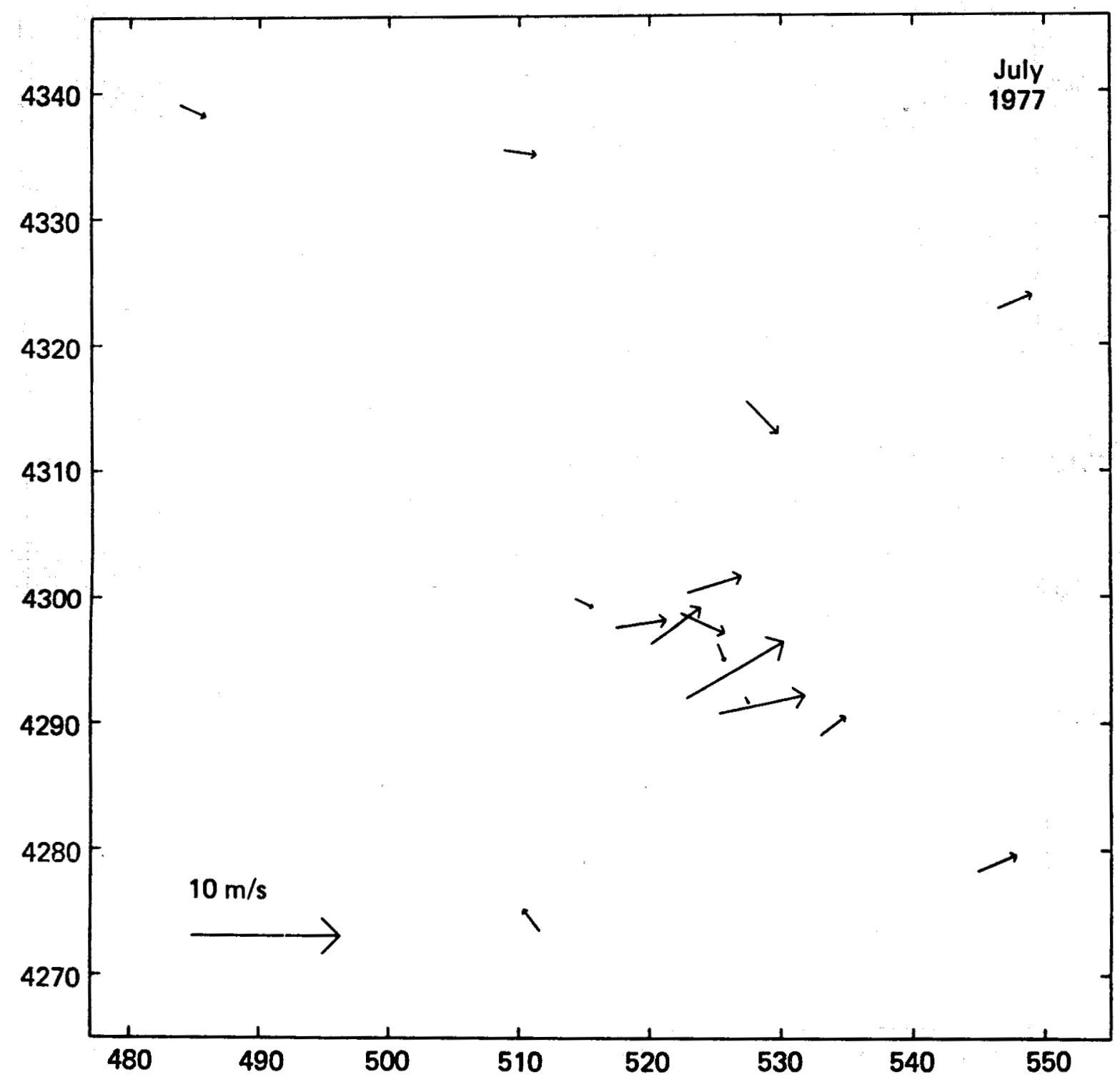

Fraction 5.04E-01

FIGURE 3. Same as Fig. 2 for the month of July 1977.

Using all 16 eigenvectors it is possible to generate a typical day at each station. This is done with a classification and fitting process. In the classification step, pairs of days are compared hour by hour in terms of the primary eigenvector expansion coefficients. If the magnitudes and directions of the coefficients lie within specific tolerances (magnitude $\pm^{\circ} 40 \%$ and direction $\pm 30^{\circ}$ ) for $60 \%$ of the 

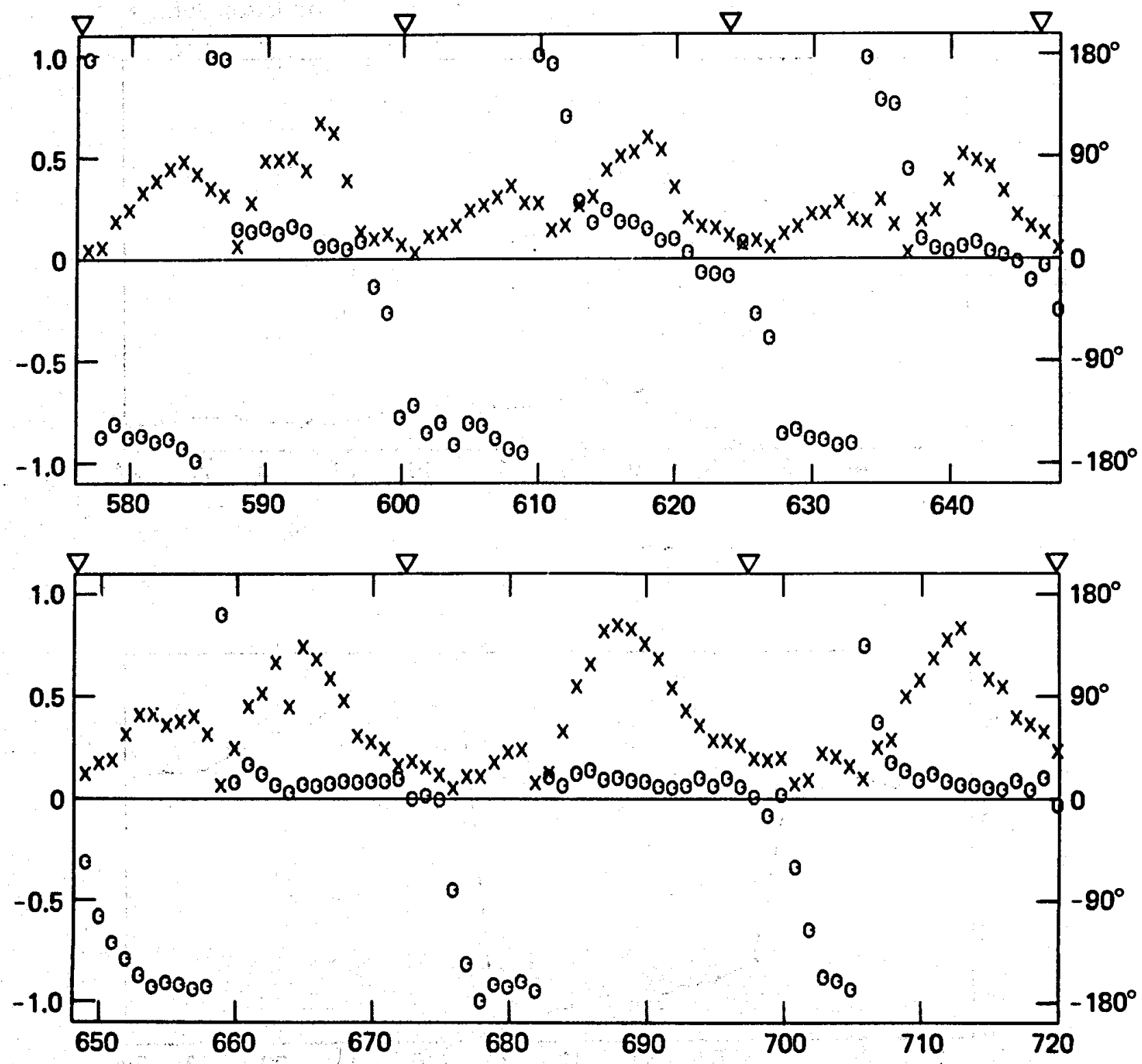

$k=1$ frac $=0.462 \times$ scale $=2.375 E+010$ scale $=180 \mathrm{deg}$

June

FIGURE 4. The complex expansion coefficients corresponding to the primary spatial eigenvector for six days selected in June 1977. The magnitude and argument of the expansion coefficients are plotted as $X$ and $O$. Relative values of the magnitude are indicated along the left ordinate; values of the argument in degrees are indicated along the right ordinate. Triangles at the top of each figure mark the position corresponding to midnight. 


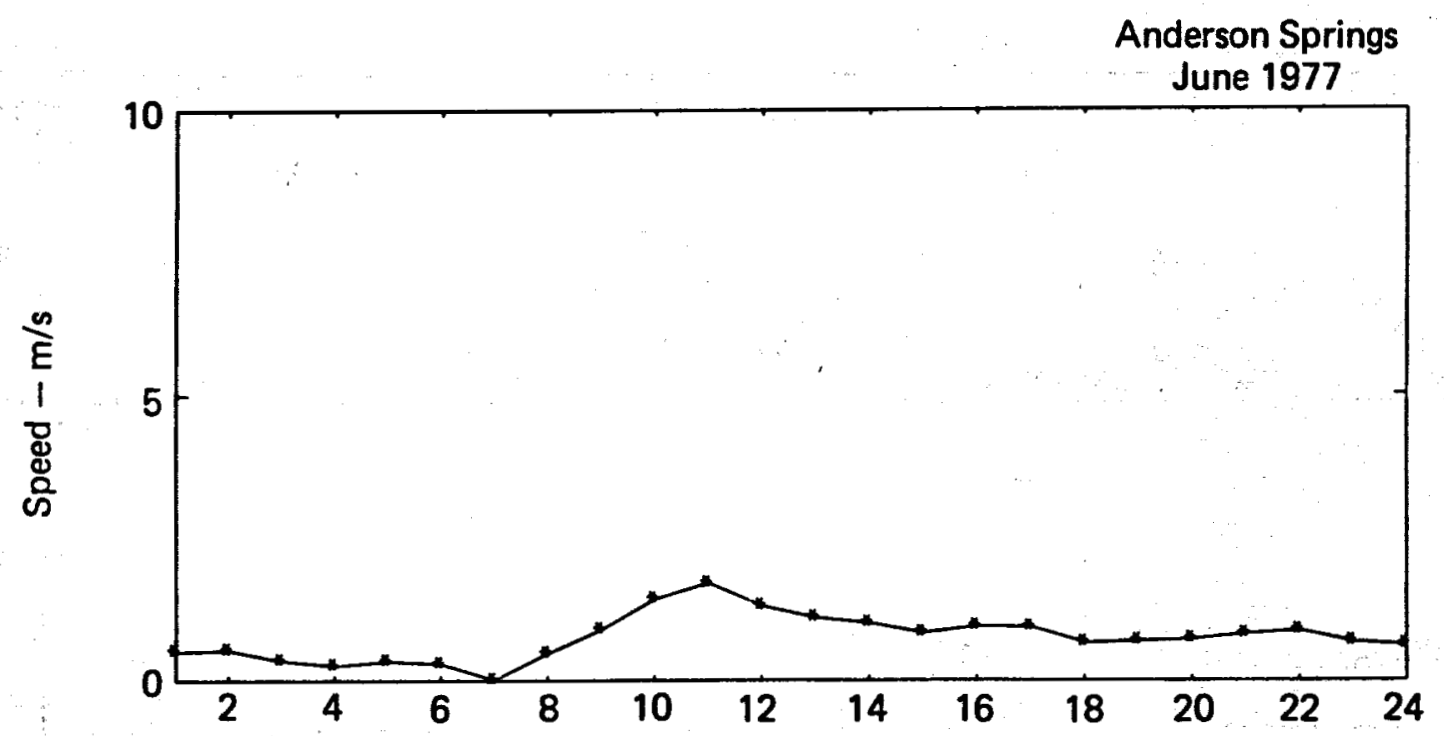

Station 1

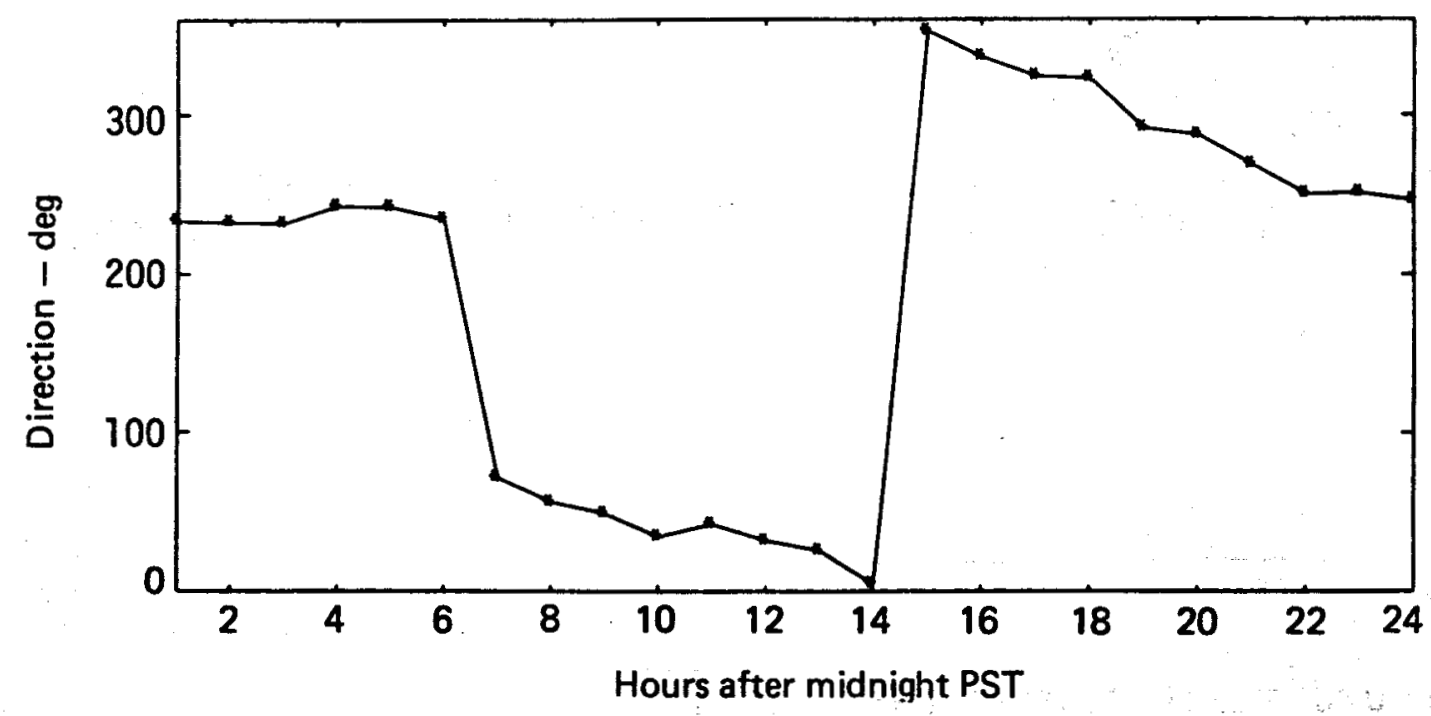

FTGURE 5. Typical day derived from PCA at Anderson Springs for the month of Jume 1977.

day they are said to be similar. The fit is made independently for each hour of the typical day for the subgroup, subject to a mean square wind speed constraint. The predominant patterns (typical days) for Anderson Springs and Anderson Ridge for the month of June are plotted in Figs. 5 and 6, respectively. The typical days for 


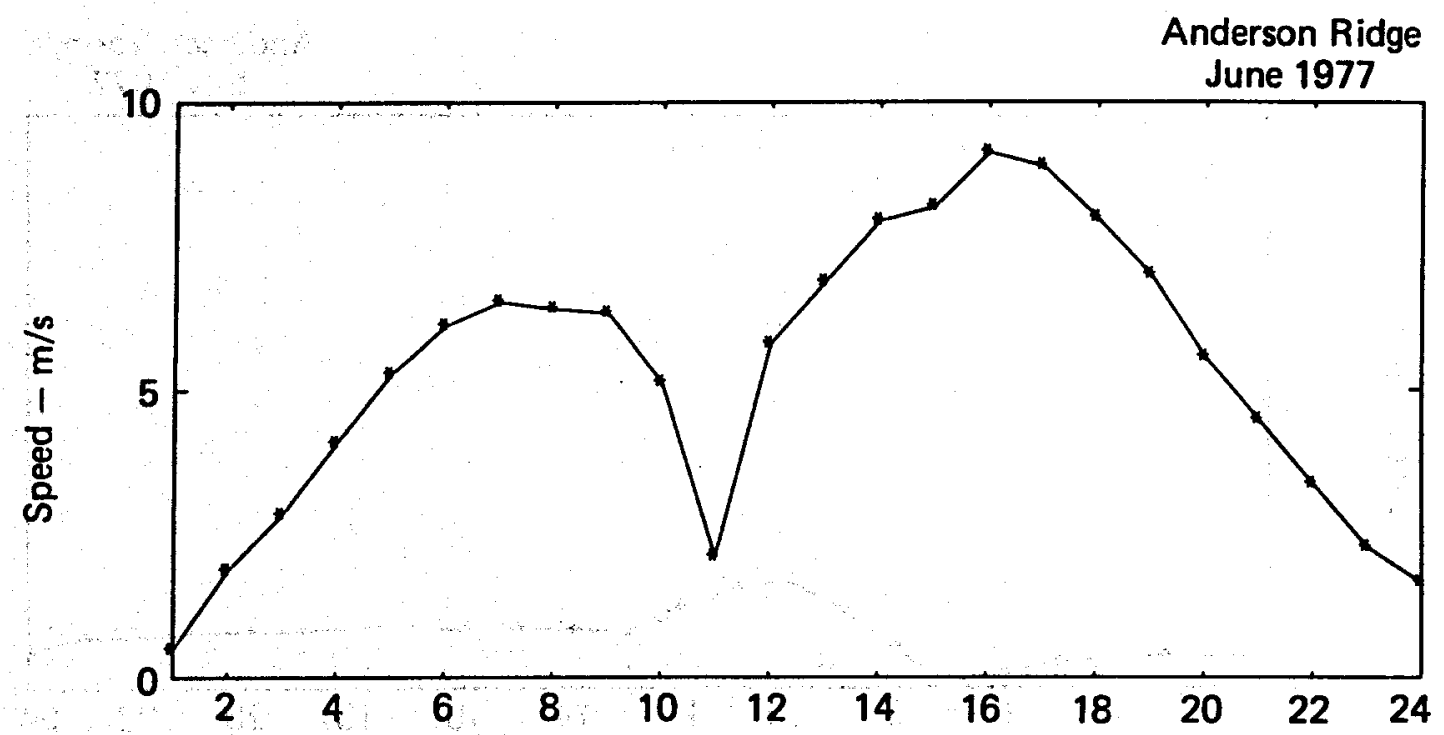

Station 16

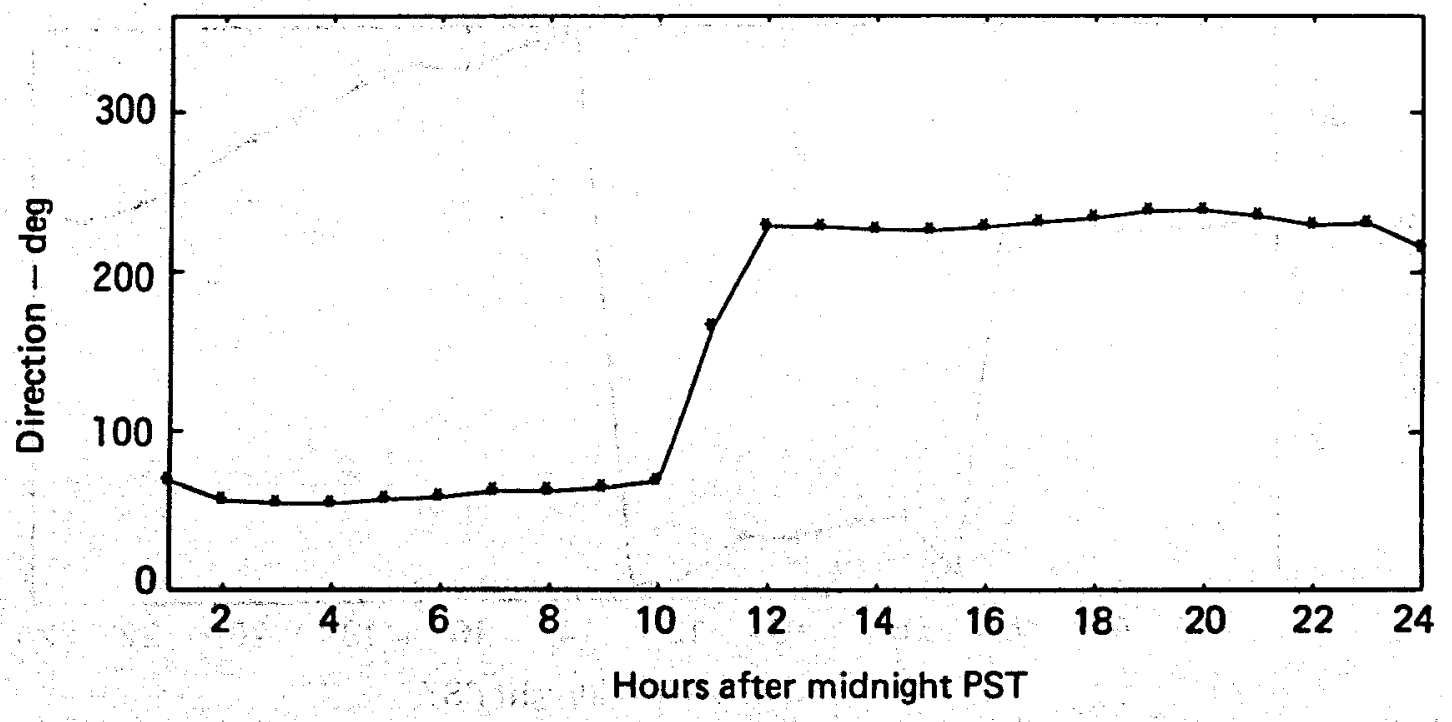

FIGURE 6. Same as Fig. 5 for Anderson Ridge.

Anderson Springs and Anderson Ridge for the month of July are plotted in Figs. 7 and 8, respectively. These typical days represent 18 days in June and 20 days in July given the above mentioned constraints. Though the typical days for Anderson Springs are very similar for June and July, they are quite different for Anderson 


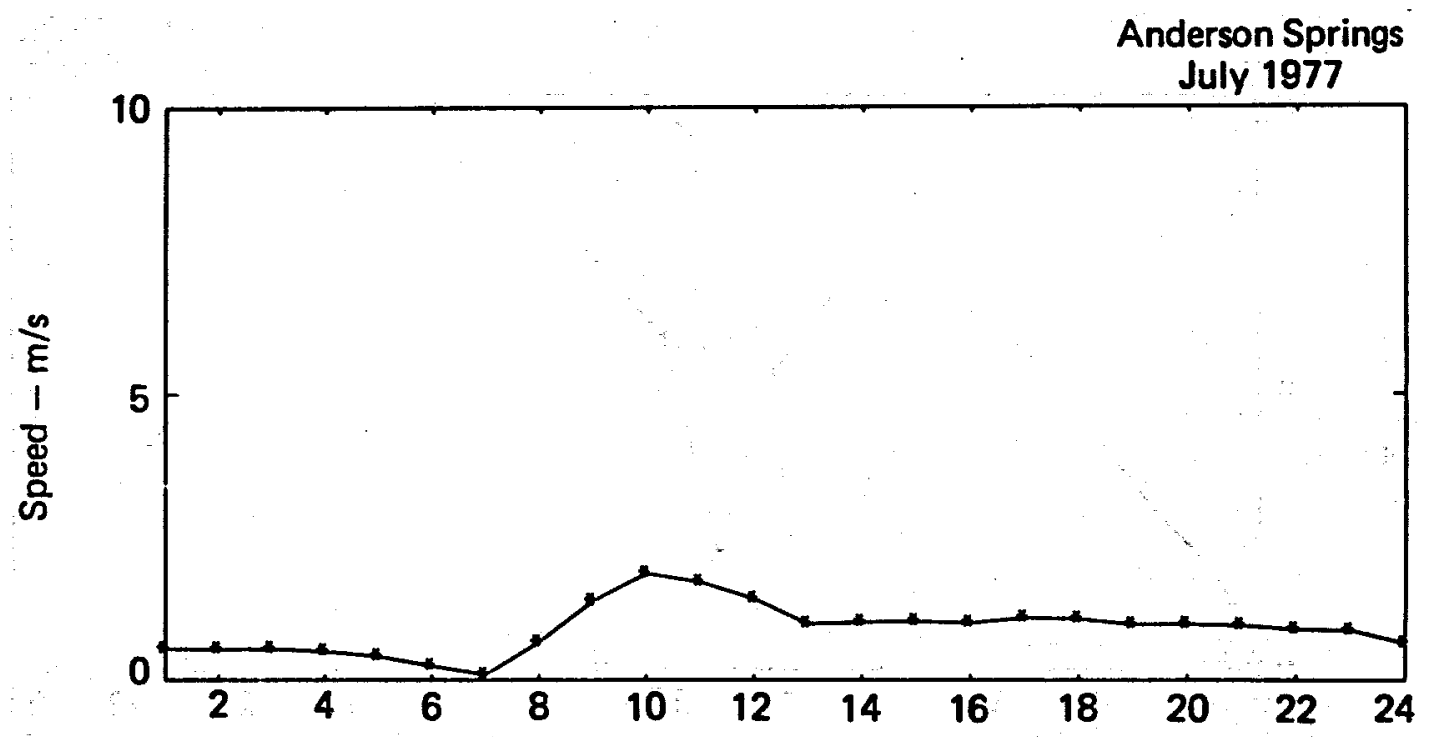

Station 1

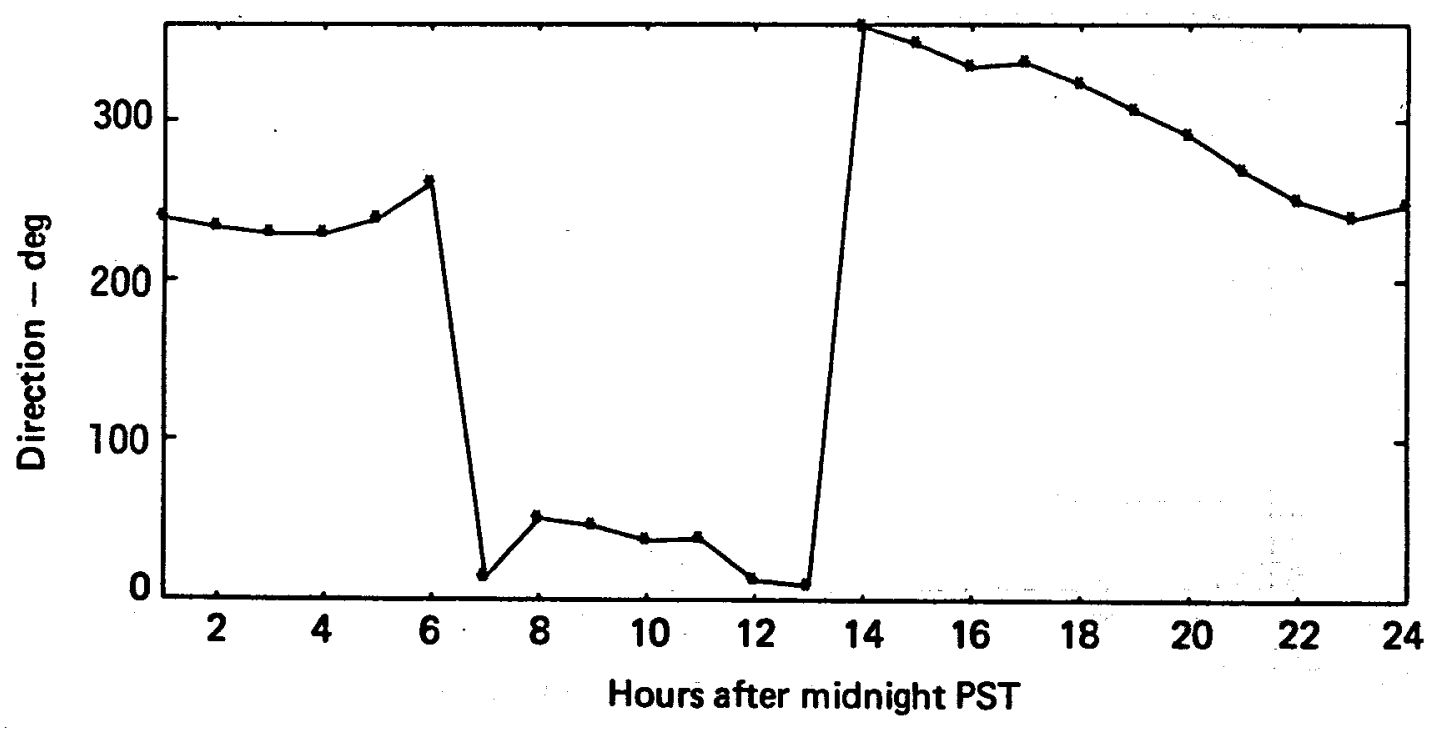

FIGURE 7. Same as Fig. 5 for the month of July 1977.

Ridge. The typical morning winds in June at Anderson Ridge are much higher than July and evidence no drainage wind $\left(\sim 270^{\circ}\right)$ direction preference. Transitions in wind direction also appear 2-6 hours sooner at Anderson Ridge than at Anderson Springs. This time delay is evident in a time-lagged correlation analysis of data from the two sites. 


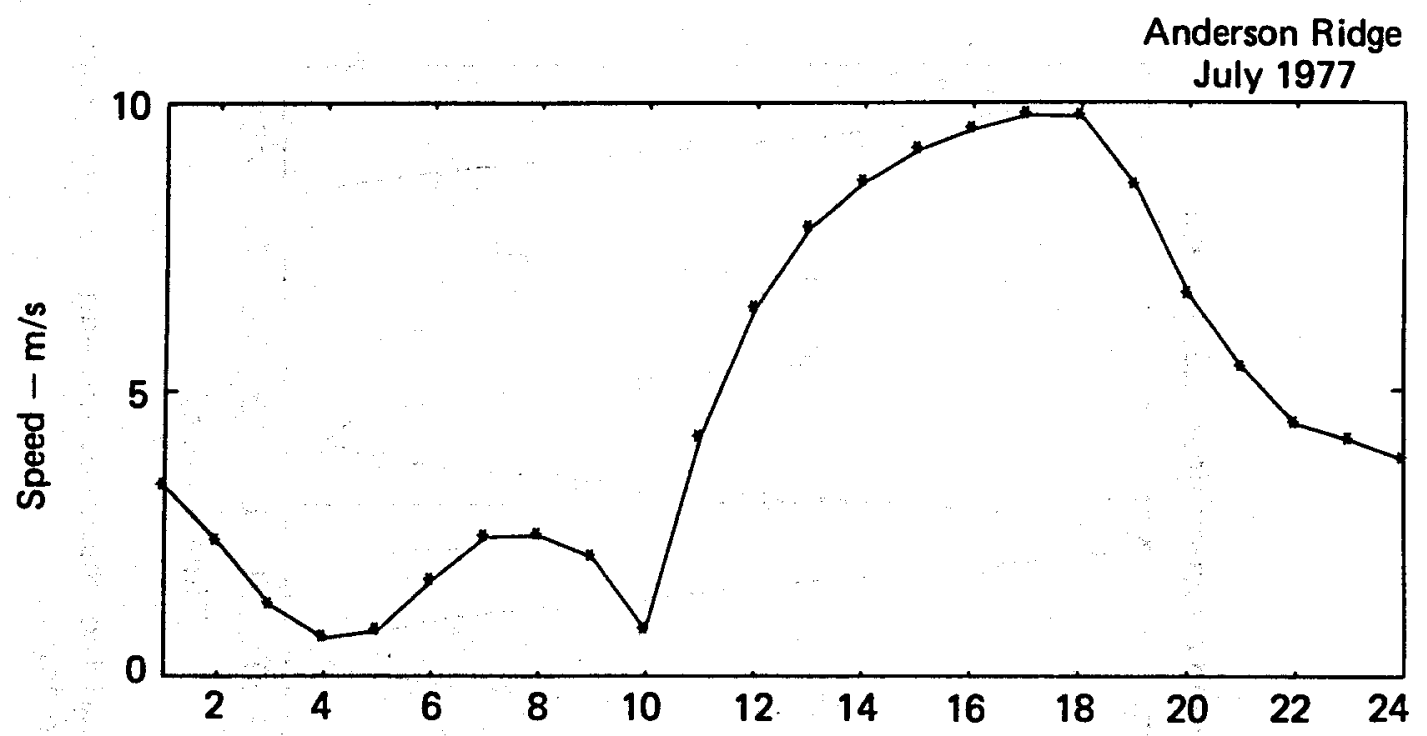

Station 16

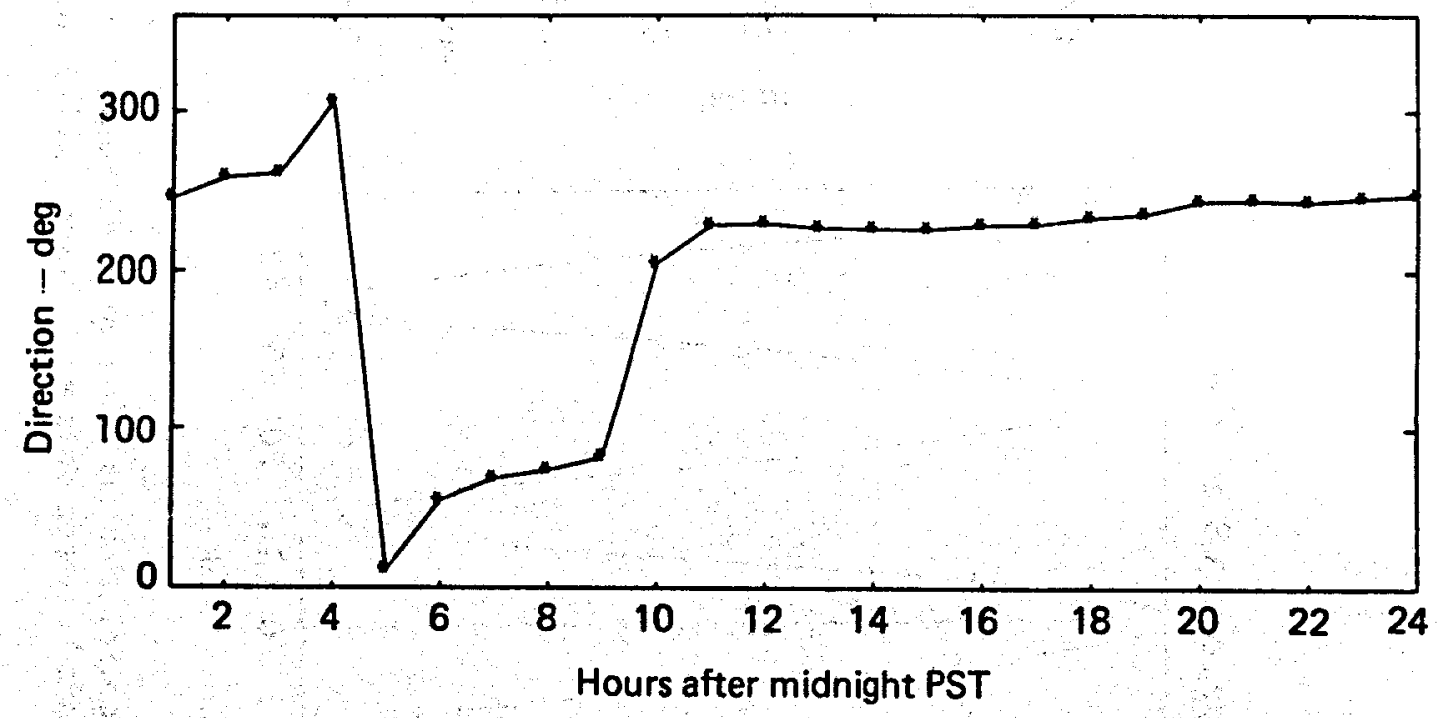

FIGURE 8. Same as Fig. 7 for Anderson Ridge.

Figure 9 shows the 48-hour time lag correlation function for wind speeds and cosine of wind direction from west-east between Anderson Ridge and Anderson Springs for the July data. The correlation function for wind speed shows no delay and peaks at a positive value at zero time lag. This shows the overall dominance of 
Wind spd. tlag corr A.S. and A.R.

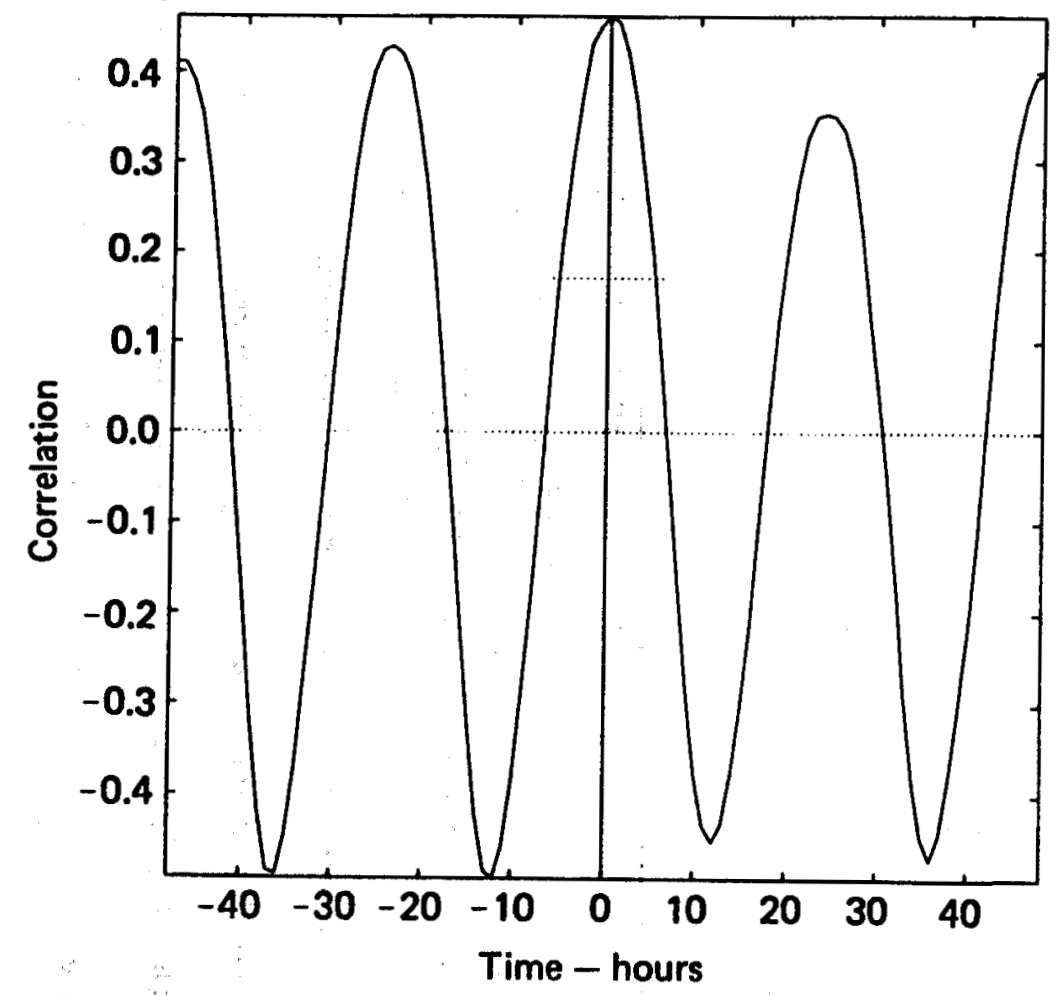

Cos wind direction tlcor A.S. and A.R.

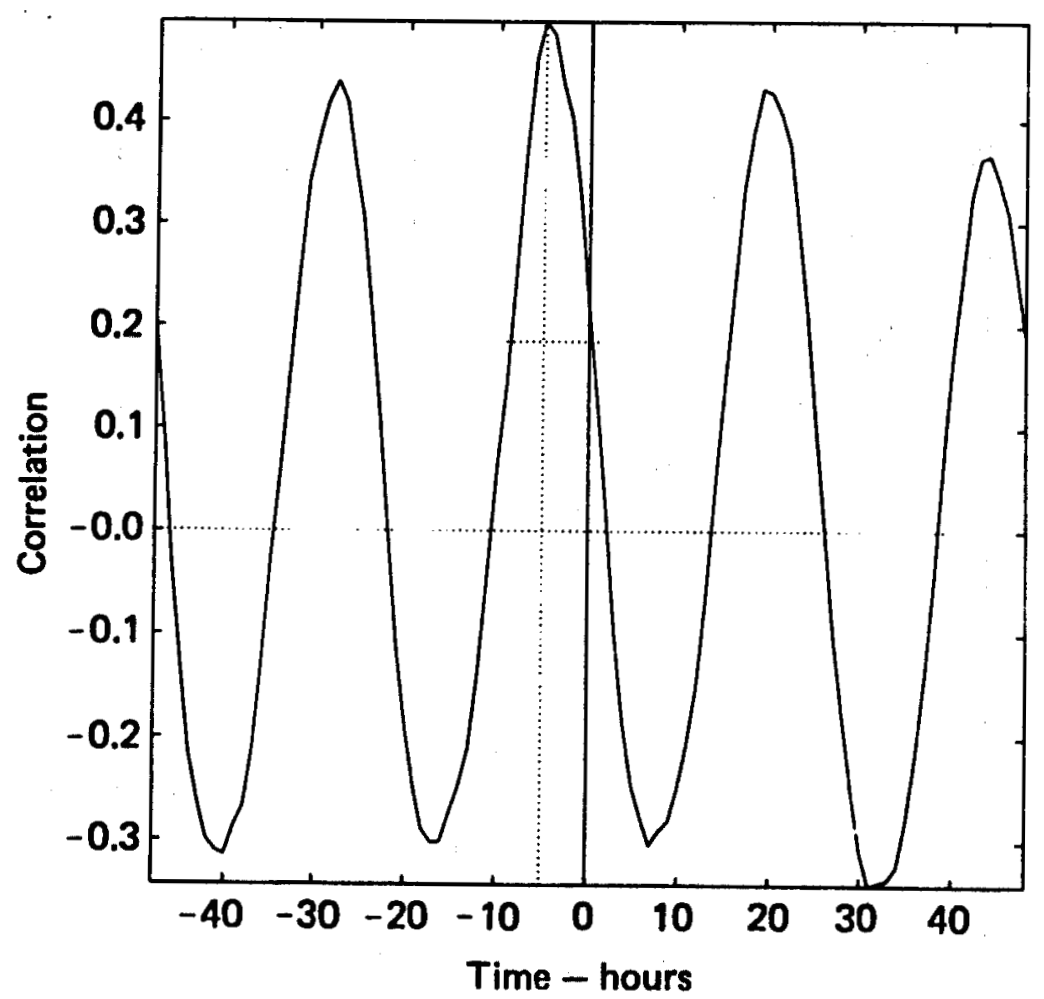

FIGURE 9. Time lagged correlation function up to 48 hours for wind speed and the cosine of the angular departure from west winds between data at Anderson Ridge and Anderson Springs. 
the U-component over the V-component (Table 2) in the total wind speed correlation. However, the cosine of wind direction away from the U-component shows a 5 hour delay between transitions in wind directions at Anderson Springs compared to Anderson Ridge. Again, this delay in wind direction changes can be seen in a comparison of July typical days shown in Figs. 7 and 8.

The complete frequency dependence of the variability of the data at Anderson Ridge and Anderson Springs can be determined through spectral analysis. Figure 10 shows the normalized autospectral density per unit frequency (cycles per day) for the U-component of the wind (over 72 days of hourly data) for Anderson Ridge and Anderson Springs. These spectra are strikingly different in overall shape and energy in the high and low frequencies. Both spectra show a strong diurnal peak and relatively strong once per 12 hour peak. Analogous spectra are shown in Fig. 11 for the $\mathrm{V}$-component of the winds. A study of wind spectra during June and July of the same year at a windy pass dominated by summer sea breeze effects $3 \mathrm{~km}$ east of Lawrence Livermore Laboratory showed much less of a 12 hour cycle and a much stronger low frequency oscillation at about once per 5 days. The windy pass spectra had a general shape more closely resembling Anderson Ridge than Anderson Springs. ${ }^{4}$ This five day variation in the intensity of the summer sea-breeze may represent a synoptic modulation, a raising or lowering of the mixing height associated with filling the Great Valley with cooler air, an ocean current modulation or a combination. It appears, therefore, that the overall humped shape of the spectra at Anderson Ridge and the relatively higher energy in the spectra at lower frequency is a result of the greater influence of the summer sea-breeze. The once per 12 hour peak shows the twice daily increase and decrease of the wind and direction changes associated with seabreeze and drainage wind conditions. Inspection of the spectra of the cosine of the wind direction shown in Fig. 12 
West-East comp. Anderson Sp. and Anderson Rdg.

要
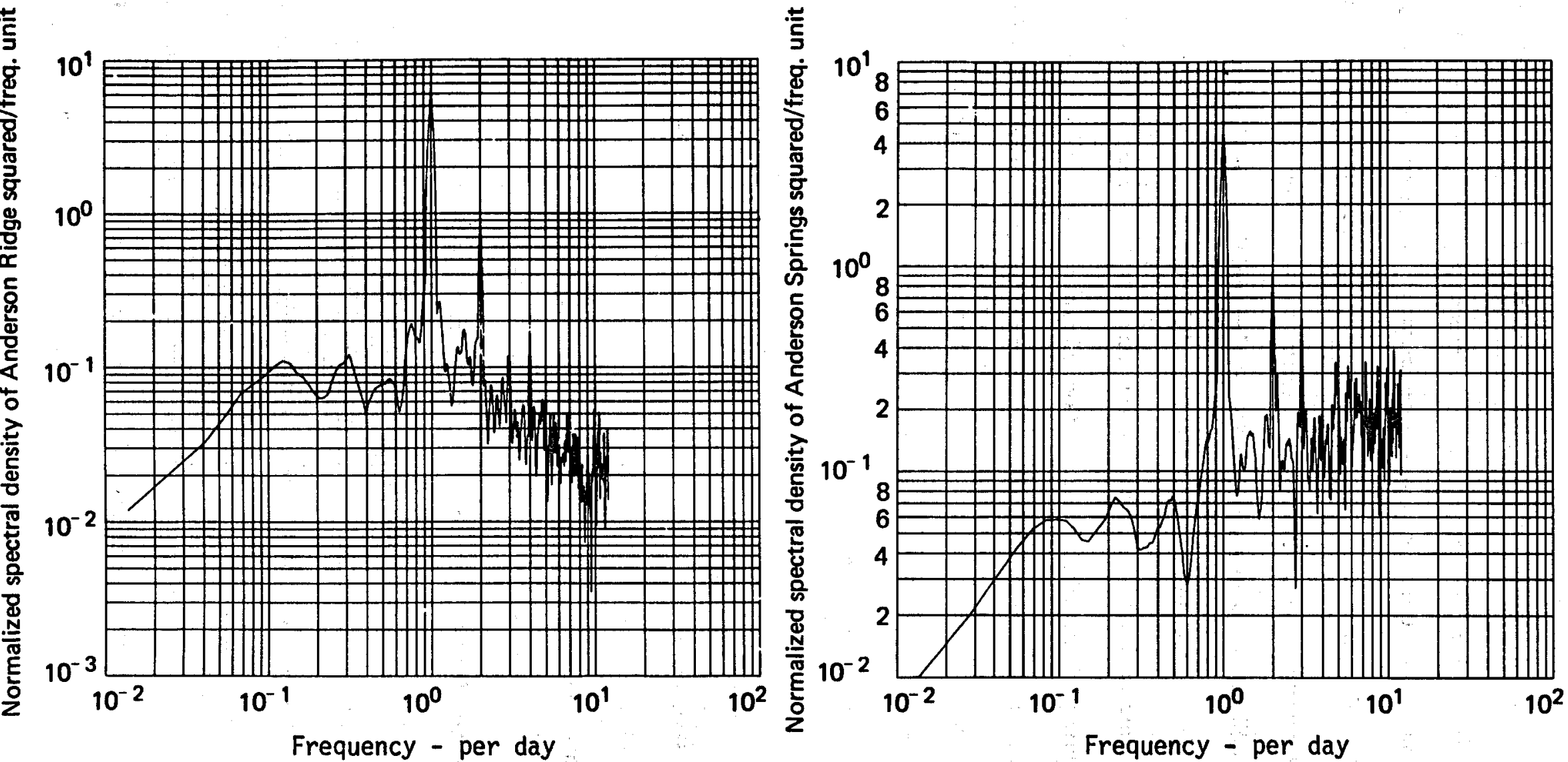

$\stackrel{1}{1}$

FIGURE 10. Normalized autospectral densities for the U-components of the wind speeds at Anderson Ridge and Anderson Springs for 72 days in the summer of 1977. 
North-South comp. Anderson Sp. and Anderson Rdg.

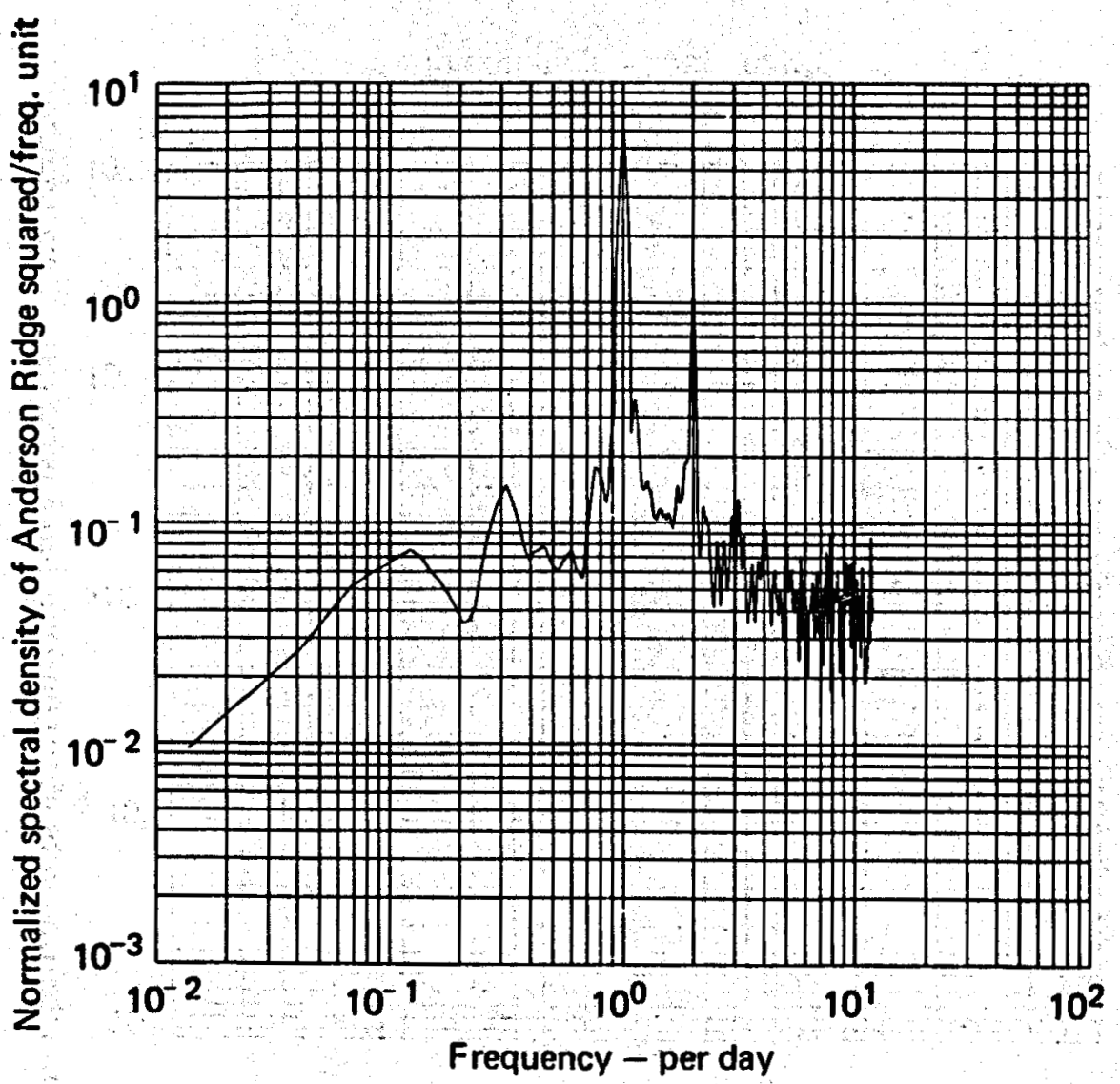

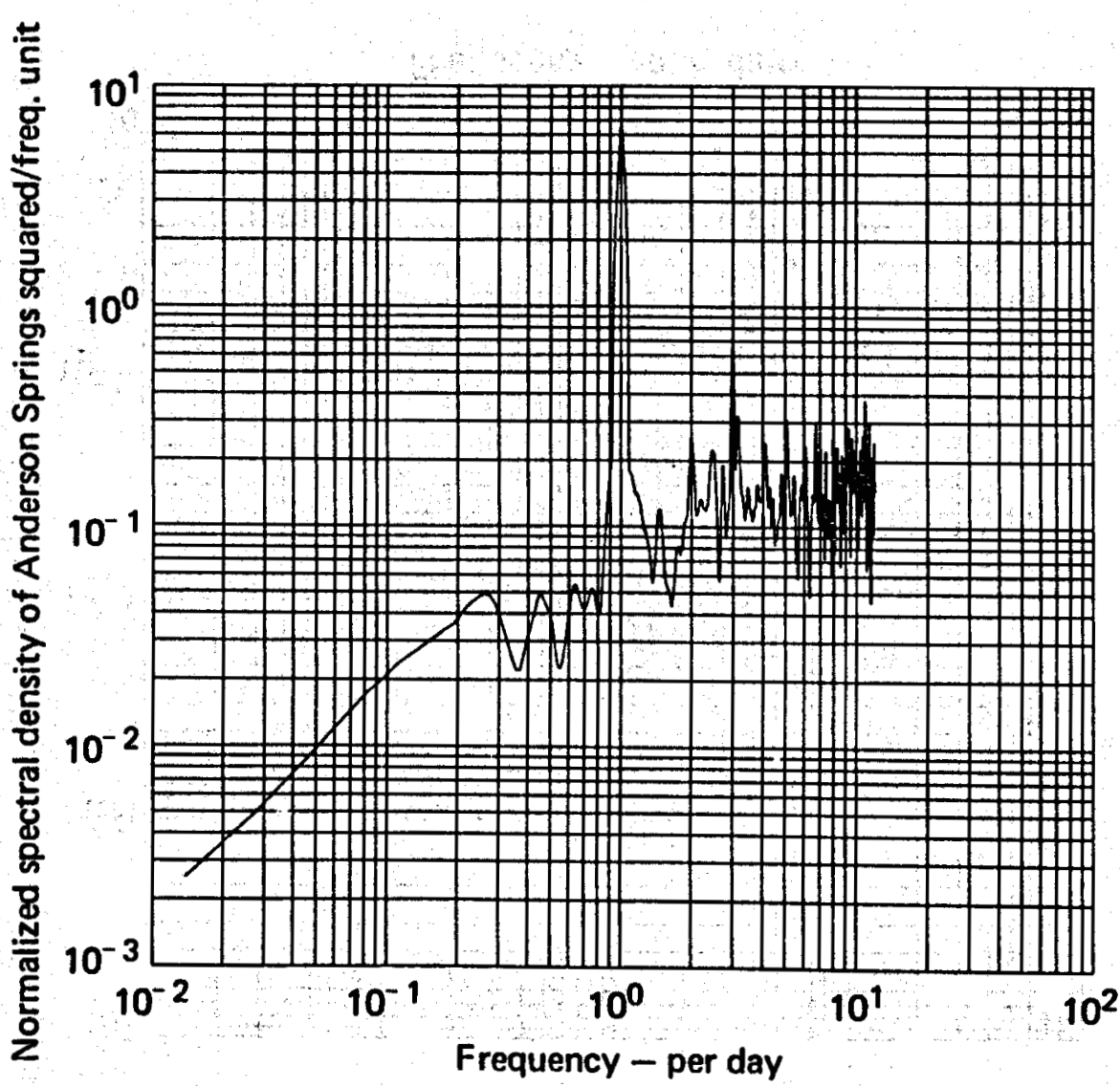

钲

FIGURE 11. Same as Fig. 10 for the V-components. 

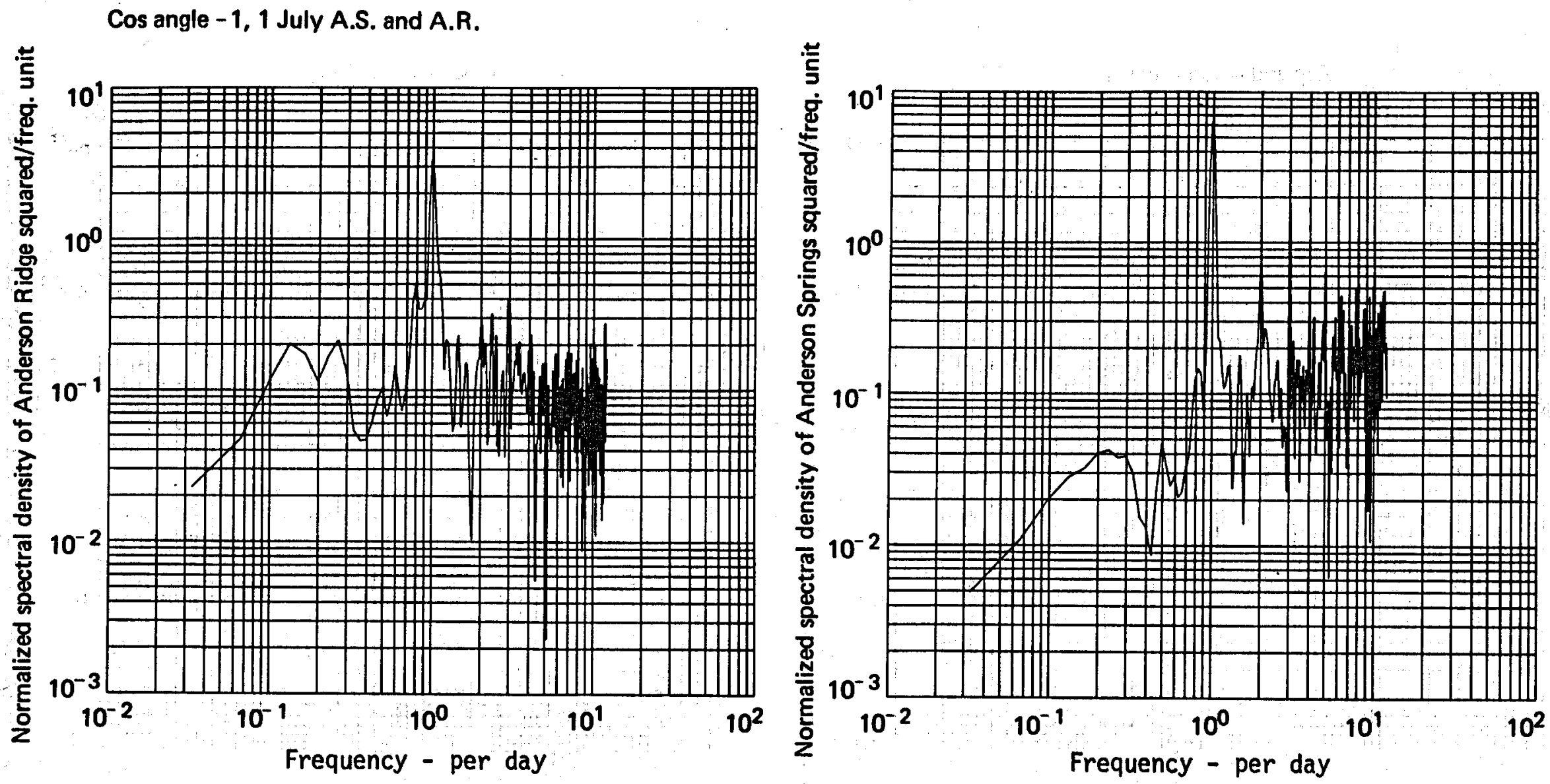

$\stackrel{1}{1}$

FIGURE 12. Same as Fig. 10 for the cosine of the wind direction component from west winds for the month of July 1977. 
shows that the contribution of wind direction to the once per 12 hour peak is much less at Anderson Ridge than Anderson Springs. There is also a considerably greater influence of wind direction changes in the lower frequencies at Anderson Ridge than Anderson Springs.

\section{CONCLUSIONS}

Statistical analysis of the spatial-temporal variability of summer winds in the Geysers geothermal area in 1977 has provided results which can be later used to quantify year to year changes especially as they impact ASCOT intensive field experiments. The statistical procedures themselves have yielded valuable insight into data quality, relationships between winds in different locations, and monthly, daily and hourly changes associated with synoptic, sea breeze and drainage wind phenomena. The major results of this study are the following:

1. Analysis of the data shows that, as expected, a down valley sheltered location (Anderson Springs) is more strongly influenced by nightime drainage wind and less influenced by summer sea-breeze winds than a ridge location (Anderson Ridge).

2. Most of the available data stations in 1977 are more closely related statistically to Anderson Ridge than Anderson Springs implying that they are not well suited for drainage wind studies in the Anderson Creek valley.

3. The regional wind patterns in the area are similar for the separate months of June and July. 
4. Eigenvector techniques and time-lagged correlation show that changes in wind direction occur sooner at Anderson Ridge than Anderson Springs.

5. Spectral analysis shows that it is possible to separate on a frequency basis drainage wind and large scale phenomena.

These results imply that closer attention should be paid to the effect of larger scale regional wind systems (possibly the sea breeze) than we had anticipated earlier in the ASCOT drainage wind studies. A preliminary suggestion has been made that at least two upper air sounding stations be placed near but outside of the Anderson Springs area to measure winds and temperature to several kilometers above terrain during the September 1980 ASCOT field experiment in the Geysers area. We strongly support this recommendation and add that dew point temperature also be

measured at these locations. Fosberg ${ }^{2}$ has shown that marine air can be traced in to the Sacramento Valley by measuring dew point temperatures. The marine and inversion air masses can be easily separated through dew point measurements. Also, several surface locations in addition to the vertical profiles within the Anderson Valley should be equipped to measure dew point temperature which could give an indication of any mixing that might take place during the experimental period.

\section{ACKNOWLEDGEMENTS}

The authors would like to thank Drs. P. Gudiksen and M. Dickerson for their support and useful ideas as well as the agencies whose efforts made this data available, Pacific Gas and Electric Co., Lake County Air Pollution Control District, North Sonoma County Air Pollution Control District, ERT and SRI International. We 
would also like to especially thank Ms. C. Castro for her programming support, and Dr. Teymoor Gedayloo for helping with editing and useful suggestions.

This work was performed under the auspices of the U. S. Department of Energy by the Lawrence Livermore Laboratory under contract No. W-7405-Eng-48.

\section{REFERENCES}

1. Walton, J. J., and D. M. Hardy, "Principal Components Analysis and its Application to Wind Field Pattern Recognition", Lawrence Livermore Laboratory Report UCRL-52488, 1978.

2. Fosberg, M. A., and M. J. Schroeder, "Marine Air Penetration in Central California," J. Appl. Meteoro., 5, pp. 573-589, 1966.

3. Draper, N. and H. Smith, Applied Regression Analysis, Wiley and Sons, New York, 1966.

4. Porch, W. M., P. A. Volker, K. R. Peterson, R. L. Weichel and C. A. Sherman, "A Regional Wind-Field Study in Complex Terrain during Summer Sea-Breeze Conditions", Lawrence Livermore Laboratory Report UCRL-52680, 1979.

FLW/1036/109 
This report was prepared as an account of work sponsored by the United States Government. Neither the United States nor the United States Department of Energy, nor any of their employees, nor any of their contractors, subcont ractors, or their employees, makes any warranty, express or implied, or assumes any legal liability or responsibility for the accuracy, completeness or usefulness of any information, apparat us, product or process disclosed, or represents that its use would not infringe privately owned rights.

Reference to a company or product name does not imply approval or recommendation of the product by the University of California or the U.S. Department of Energy to the exclusion of others that may be suitable.

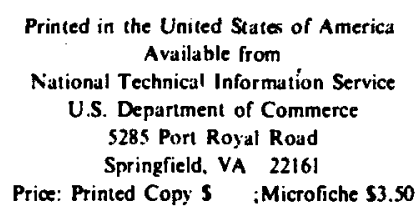

\begin{tabular}{|c|c|c|c|}
\hline Page Range & $\begin{array}{c}\text { Domestic } \\
\text { Price } \\
\end{array}$ & Page Range & $\begin{array}{c}\text { Domestic } \\
\text { Price } \\
\end{array}$ \\
\hline $001-025$ & S 5.00 & $326-250$ & $\$ 18.00$ \\
\hline $026-050$ & 6.00 & $351-375$ & 19.00 \\
\hline $051-075$ & 7.00 & $376-400$ & 20.00 \\
\hline $076-100$ & 8.00 & $401-425$ & 21.00 \\
\hline $101-125$ & 9.00 & $426-450$ & 22.00 \\
\hline $126-150$ & 10.00 & $451-475$ & 23.00 \\
\hline 151.175 & 11.00 & $476-500$ & 24.00 \\
\hline $176-200$ & 12.00 & 501.525 & 25.00 \\
\hline $201-225$ & 13.00 & $526-550$ & 26.00 \\
\hline $226-250$ & 14.00 & $551-575$ & 27.00 \\
\hline $251-275$ & 15.00 & $576-600$ & 28.00 \\
\hline $276-300$ & 16.00 & 601 -up 1 & \\
\hline $301-325$ & 17.00 & & \\
\hline
\end{tabular}

Work performed under the auspices of the U.S. Department of Energy by the Lawrence Livermore Laboratory under Contract W-7405-Eng-48. 